\title{
I've Never Been Able To Write!
}

I have never yet written

I've only scribbled this or that nor was it ever true

I now can write and can see, what it is.

True.

Such truth as is reality itself, like that which is not like itself

A mathematical dream:

An absolute good. On the cube.

Now I will write no more, l'll merely jeer.

Jeer even Anatole France himself and I surely can write yet surely more can cry and even more can endure... if someone requires it of me.

It bothers me greatly that there is no reasoner... measurer.

Since I cannot write poetry

I'm trying it more often. Perhaps then it will be beautiful

The way kitsch was, like an alien continent,

Where never before have I walked and yet

Have led there among great dangers... others

And could do it bravely.

And on a little branch I walked there myself.

I've just seen it. It was not a joy ride, just

what was shown to me by those fevered, willing friends

Since then l've feared having a passion.

Like cocaine. Like this familiar moment (?)...

Hypnotized. Useful. Custom-made. 